\title{
Diethanolamine-Induced Alteration of Hepatic Mitochondrial Function and Structure ${ }^{1}$
}

\author{
S. J. BARBEE ${ }^{2}$ AND R. HARTUNG \\ Department of Environmental and Industrial Health, School of Public Health, \\ University of Michigan, Ann Arbor, Michigan 48109
}

Received November 18, 1977; accepted July 31, 1978

\begin{abstract}
Diethanolamine-Induced Alteration of Hepatic Mitochondrial Function and Structure. Barbee, S. J., and Hartung, R. (1979). Toxicol. Appl. Pharmacol. 47, 431-440. Diethanolamine (DEA) has been shown to interfere with phospholipid metabolism. It was hypothesized that DEA may alter membrane-bound biochemical processes which are dependent upon phospholipids. DEA was investigated for its effect on hepatic mitochondrial function and structure in the male Sprague-Dawley rat. DEA did not produce mitochondrial alterations in in vitro preparations from liver tissue. Similarly, acute treatment in vivo was without effect. However, a loss of mitochondrial integrity developed after subacute administration of DEA. Rats were given $0.25(42 \mathrm{mg} / \mathrm{kg} /$ day $), 1.0(160 \mathrm{mg} / \mathrm{kg} / \mathrm{day})$, or $3.0(490 \mathrm{mg} /$ $\mathrm{kg} /$ day) $\mathrm{mg} / \mathrm{ml}$ in their drinking water for varying periods up to 5 weeks. The effects on mitochondria were dose- and time dependent. Significant alterations appeared after 3 days at $3.0 \mathrm{mg} / \mathrm{ml}$ and after 1 week at $1.0 \mathrm{mg} / \mathrm{ml}$. Mitochondrial State 4 acitivity was significantly elevated at all three dose levels following 2 weeks of DEA treatment. Concomitantly, an increase was noted in the $\mathrm{Mg}^{2+}$-dependent ATPase activity from rats treated with DEA at $2.0 \mathrm{mg} / \mathrm{ml}$ for 3 weeks. Electron micrographs indicated that treated animals had swollen hepatic mitochondria. The changes in the organelle may be related to alteration of phospholipid metabolism by DEA.
\end{abstract}

Diethanolamine (DEA), a member of a class of compounds known as the alkanolamines, is used in the chemical industry as an intermediate in the production of detergents, solubilizers, and textile finishing agents, and as an absorbent for acidic gases (Sutton, 1963). It is used in the pharmaceutical industry as a buffer and stabilizer for certain drugs (Soreat, 1973). Many biologically

${ }^{1}$ This work is part of a thesis submitted to the University of Michigan in partial fulfillment of the requirements for the degree of Doctor of Philosophy. A preliminary report of this work was presented at the Fifteenth Annual Meeting of the Society of Toxicology.

${ }^{2}$ Present address: Department of Environmental Hygiene and Toxicology, Olin Corporation, 91 Shelton Avenue, New Haven, Conn. 06511. exogenous alkanolamine compounds have been shown to interact with phospholipid metabolism (Welch and Landau, 1942; Wells and Remy, 1961; Chaplin and Mulford, 1961; Chojnacki and Korzybski, 1963; Morin, 1969). DEA can be incorporated in vivo into hepatic phospholipids (Artom et al., 1958; Barbee and Hartung, 1979) and can inhibit the in vitro and in vivo synthesis of phospholipid derivatives of choline and ethanolamine (Barbee and Hartung, 1979). Choline and ethanolamine are essential in lipid metabolism (Fleischer and Rouser, 1965; Fleischer et al., 1967) and membranebound enzymatic processes (Green, 1959; Green and Fleischer, 1963; Lenaz, 1973). The ability of DEA to compete with choline 
and ethanolamine in phospholipid metabolism raises the question of whether it exerts an effect on membrane-bound enzymatic processes. Foster (1971) noted that repeated oral administration of DEA reduced the activity of hepatic microsomal drug-metabolizing enzymes from the rat. This information suggests that DEA may exert an effect on other membrane-bound cellular processes.

The purpose of this study was to investigate whether DEA alters the function and structure of the mitochondrion from hepatic tissuc of the rat. This organelle was chosen for study because it is dependent upon phospholipids for proper function (Green and Fleischer, 1963) and it is intimately involved in cell metabolism (Chance and Hollunger, 1961 ; Chance, 1961).

\section{METHODS}

Male albino rats of the Sprague-Dawley strain were used throughout this investigation at an initial weight of $150-200 \mathrm{~g}$. They were maintained in airconditioned quarters and supplied with food and water ad libitum. All animals were allowed to acclimate for at least 3 days before they were used in experimentation. Sacrifice was accomplished by exsanguination via open chest heart puncture after the animal was anesthetized with ether.

Diethanolamine (DEA) was purchased from the J. T. Baker Chemical Company, and it was used without further purification.

DEA was obtained as the free base, and as such was not suitable for direct administration because of its high $\mathrm{pH}$ in water. A desired amount of DEA was placed in a beaker with an equal volume of water. The beaker was placed in a water ice bath and neutralized to $\mathrm{pH} 7.4$ with $\mathrm{HCl}$. Throughout the neutralization process, the temperature was kept below $30^{\circ} \mathrm{C}$ to minimize alteration of the compound.

The in vitro and acute in vivo effect of DEA on hepatic mitochondria was assayed at $5 \mathrm{~mm}$ and $490 \mathrm{mg} / \mathrm{kg}$, respectively. To assess the subacute in vivo effect of this substance on hepatic mitochondrial function DEA was administered in the drinking water according to the following dosing regimen: $0.25 \mathrm{mg} / \mathrm{ml}$ (42 mg/kg/day) for 2 and 5 weeks, $1.0 \mathrm{mg} / \mathrm{ml}(160 \mathrm{mg} / \mathrm{kg} /$ day $)$ for 1,3 , and 5 weeks, and $3.0 \mathrm{mg} / \mathrm{ml}(490 \mathrm{mg} / \mathrm{kg} / \mathrm{day})$ for 1 day, 3 days, and $1,2,3$, and 5 weeks. Water consumption was monitored to approximate the dose consumed in $\mathrm{mg} / \mathrm{kg} /$ day. The dosages were calculated in terms of the free base.
Hepatic mitochondria were isolated according to the method of Brabec et al. (1974). The respiratory rate, acceptor control ratio, and $\mathrm{ADP} / \mathrm{O}$ for hepatic mitochondria were determined using a Model 53 oxygen electrode system from Yellow Springs Instrument Company as described by Estabrook (1967) in $0.15 \mathrm{~m}$ sucrose, $20 \mathrm{~mm}$ potassium chloride, $20 \mathrm{~mm}$ Tris $\left(\mathrm{pH} 7.0\right.$ at $\left.30^{\circ} \mathrm{C}\right), 10 \mathrm{~mm}$ potassium phosphate (monobasic), $5 \mathrm{~mm}$ magnesium chloride, and $100 \mathrm{~mm}$ succinate from the method of Brabec ef al. (1974).

The medium was added in a volume of $2.4 \mathrm{ml}$ combined with $0.1 \mathrm{ml}$ of succinate. The succinate was prepared by placing the desired amount in a volumetric container and adjusting the $\mathrm{pH}$ to 7.0 with potassium hydroxide. The system was maintained at $30^{\circ} \mathrm{C}$ in a circulating water bath. The oxygen electrode was set in place and the system was allowed to equilibrate at $100 \%$ of oxygen saturation. The nanomoles of oxygen contained in the medium were calculated based on volume and temperature (Strickland and Parsons, 1968). The assay was initiated by the addition of $50 \mu \mathrm{l}$ of mitochrondrial suspension and $200 \mathrm{nmol}$ ADP. The ADP causes an immediate increase in the ratc of oxygen utilization; this ratc (State 3) is maintained until the added ADP is phosphorylated. At this time, ADP becomes limiting and the rate of oxgyen consumption decreases (State 4). State 3 and State 4 activity may be determined by calculating the nanomoles of oxygen consumed per minute and relating this to milligrams of mitochrondrial protein added. The acceptor control ratio is determined by dividing State 3 activity by that of State 4 . The ADP/O ratio is calculated by dividing the nanomoles of ADP phosphorylated by nanoatoms of oxygen consumed during each interval at State 3.

The study to assess the subacute effects of DEA on hepatic mitochondrial membrane permeability was divided into two parts, evaluating the inner and outer mitochondrial membranes. The method and duration of administration and dose of DEA were kept constant for both investigations. Each experimental and control group consisted of four animals each. The experimental group was given $3.0 \mathrm{mg} / \mathrm{ml}$ DEA in their drinking water for 2 weeks.

Outer mitochondrial membrane permeability was assayed according to a modification of the method of Wattiaux-DeConnick and Wattiaux (1971) by following the spectrophotometric reduction of cytochrome $c$ by sulfite-cytochrome $c$ reductase at $550 \mathrm{~nm}$. Mitochrondria were prepared as previously described. The reagents consisted of a buffer, prepared by placing $1.0 \mathrm{ml}$ of $0.2 \mathrm{M}$ Tris and $0.1 \mathrm{~mm}$ EDTA $(\mathrm{pH} 8.5)$ in $9 \mathrm{ml}$ of isolation medium, $0.01 \mathrm{~m}$ sodium sulfite, $0.25 \mathrm{~mm}$ cytochrome $c, 13.5 \mathrm{~mm}$ potassium cynaide, buffered to $\mathrm{pH} 8.0$ with the Tris-EDTA solution described above, and mitochondria diluted 
1: 10 with $0.25 \mathrm{M}$ sucrose just prior to assay to achieve 2-3 mg protein $/ \mathrm{ml}$. Two milliliters of buffer, $0.1 \mathrm{ml}$ potassium cyanide, $0.1 \mathrm{ml}$ sodium sulfite, and $50 \mu \mathrm{l}$ of mitochondrial suspension were introduced into 3-ml cuvettes. In order to establish a recorded baseline, the system was allowed to equlibrate 4 min before addition of substrate. The reaction was started by adding $0.2 \mathrm{ml}$ cytochrome $c$. The progress of the reaction was monitored for approximately $20 \mathrm{~min}$ at $30^{\circ} \mathrm{C}$ in a Gilford recording spectrophotometer.

Cytochrome $c$ does not freely permeate the outer membrane. However, when the outer membrane is sufficiently altered by detergents or toxic substances, the cytochrome $c$ is free to migrate through the membrane where it is reduced, then back out into the medium where it is measured. Potassium cyanide is added to the medium to prevent the reoxidation of cytochrome $c$ by cytochrome oxidase. The activity of sulfite-cytochrome $c$ reductase is expressed as $\Delta \mathrm{OD} / \mathrm{min} / \mathrm{mg}$ protein.

The permeability of the inner membrane was determined following the method of Byard et al. (1975). Mitochondria were isolated and assayed for oxygen consumption as previously described using $\mathrm{NADH}$ instead of succinate as the substrate. The results were expressed as the difference in respiration between an excess of NADH and ADP compared to no added NADH and an excess of ADP with units given as $\mathrm{nmol} \mathrm{O}_{2} / \mathrm{min} / \mathrm{mg}$ protein. According to Van den Bergh and Slater (1962), extramitochondrial $\mathrm{NADH}$ itself cannot penetrate the mitochondrial membrane. If the mitochondria are sufficiently damaged, NADH can enter the inner compartment and be oxidized at the expense of oxygen.

Mitochondrial ATPase was measured following the method of Pederson and Morris (1974). Treated animals received $3.0 \mathrm{mg} / \mathrm{ml}$ DEA in their drinking water for 3 weeks.

Hepatic tissue was taken for ultrastructural examination as described by Sibrack et al. (1974). Animals in the treated group received drinking water containing $3.0 \mathrm{mg} / \mathrm{ml} \mathrm{DEA}$ for 2 weeks.

Protein concentration was determined by the method of Lowry et al. (1951).

Statistical significance of the data was determined by analysis of variance and Student's $t$ test.

\section{RESULTS}

DEA was ineffective in producing hepatic mitochondrial alteration in vitro; and similarly, acute in vivo treatment for $24 \mathrm{hr}$ was without effect. These data are presented in Table 1 .

When DEA was administered subacutely, it produced significant altcration of hepatic mitochondrial integrity. No significant effect was observed in renal mitochondria exposed in vitro and in vivo to DEA.

The results of the subacute effect of DEA

TABLE 1

LACK OF EFFECT of in Vitro AND ACUTE in Vivo EXPOSURE OF DEA ON HEPATIC MITOCHONDRIA ${ }^{a}$

\begin{tabular}{lcccc}
\hline & \multicolumn{4}{c}{ Mitochondrial variable } \\
\cline { 2 - 5 } Treatment & $\begin{array}{c}\text { State 3 } \\
\text { activity }\end{array}$ & $\begin{array}{c}\text { State } 4 \\
\text { activity }\end{array}$ & $\begin{array}{c}\text { Acceptor } \\
\text { control } \\
\text { ratio }\end{array}$ & ADP/O \\
\hline Control & $134.9 \pm 1.9$ & $25.2 \pm 0.5$ & $5.37 \pm 0.03$ & $1.46 \pm 0.02$ \\
In vitro & $140.4 \pm 2.2$ & $25.9 \pm 0.6$ & $5.42 \pm 0.04$ & $1.45 \pm 0.01$ \\
In vivo & $135.8 \pm 3.0$ & $25.7 \pm 0.7$ & $5.29 \pm 0.03$ & $1.45 \pm 0.02$ \\
\hline
\end{tabular}

a Animals administered the acute dose received $3 \mathrm{mg} / \mathrm{ml}(490 \mathrm{mg} / \mathrm{kg} /$ day) DEA in their drinking water for $24 \mathrm{hr}$. The in vitro effect was determined by isolating control mitochondria and assaying them in the presence of $5 \mathrm{mM}$ DEA. Each value represents the mean $\pm S E$ of data from at least four animals.

${ }^{b}$ Expressed as nmol $\mathrm{O}_{2} / \mathrm{mg}$ protein $/ \mathrm{min}$.

' Expressed as the ratio of State 3/State 4.

- Expressed as the ratio of nmol ADP phosphorylated to natoms $\mathrm{O}_{2}$ consumed during State 3 respiration. 
on hepatic mitochondrial State 4 activity and acceptor control ratio are presented in Fig. 1. The data indicate a continued increase in State 4 for up to 3 weeks of DEA administration, after which it remains at more or less constant levels compared to those attained after 3 weeks of dosing. The increases in State 4 are dependent both on the dose and the duration of administration. DEA given at $1.0 \mathrm{mg} / \mathrm{ml}$ for 1 week produces no increase compared to controls, whereas $3.0 \mathrm{mg} / \mathrm{ml}$ for the same time produces a $9 \%$ increase. When $1.0 \mathrm{mg} / \mathrm{ml}$ is given for 3 weeks, a $45 \%$ increase is seen. The dose at $0.25 \mathrm{mg} / \mathrm{ml}$ increases State 4 activity to only $12 \%$ above controls after 2 weeks, and this level is main-
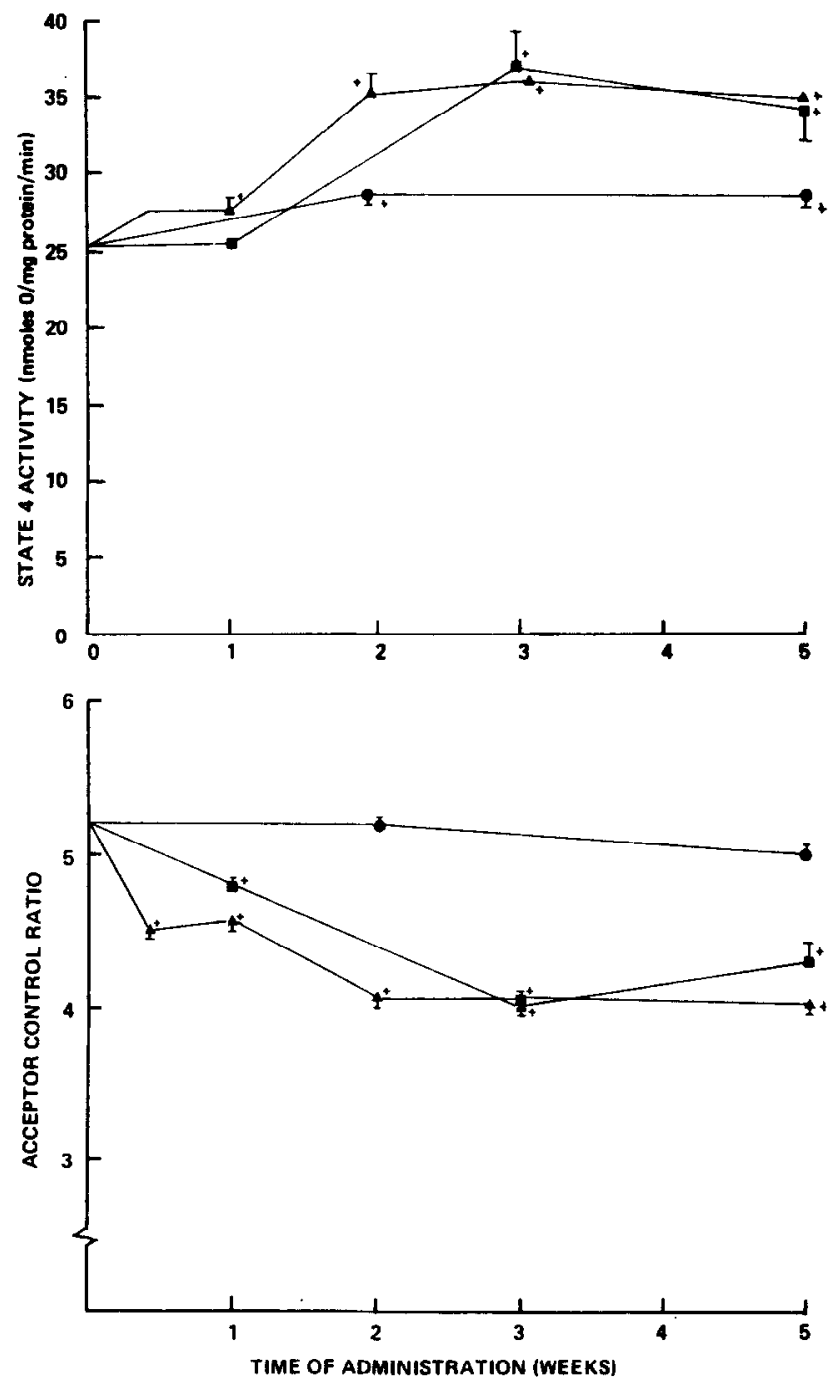

FIG. 1. The upper figure represents hepatic mitochondrial State 4 activity after subacute oral administration of DEA. The lower figure represents hepatic mitochondrial acceptor control ratio after subacute oral administration of DEA. DEA was administered orally in drinking water at $0.25 \mathrm{mg} / \mathrm{ml}(42 \mathrm{mg} / \mathrm{kg} /$ day $)$ 
tained throughout 5 weeks of administration. Significant differences were obtained for all values except after $1.0 \mathrm{mg} / \mathrm{ml}$ DEA for 1 week.

The decline in the acceptor control ratio (ACR) in hepatic mitochondria is the result of an increase in State 4 since no change was observed in State 3 activity. As with State 4 activity, the effect on the ACR is dose and time dependent. The only dose which did not show a significant difference from control values is that at $0.25 \mathrm{mg} / \mathrm{ml}$. The ACR calculated for animals receiving 1.0 and $3.0 \mathrm{mg} / \mathrm{ml}$ declined to $75 \%$ of control after 2 and 3 weeks of administration. This value is maintained for both dose levels through 5 weeks of testing.

To provide an explanation for the increase in State $4, \mathbf{M g}^{2+}$-dependent ATPase was determined in animals given $3.0 \mathrm{mg} / \mathrm{ml}$ DEA for 2 weeks (Table 2). A significant increase in the activity of this enzyme occurred. The rise was comparable to that observed for State 4 activity. Since State 4 activity is defined as respiration in the absence of ADP, any endogenous process providing a source of ADP would stimulate electron transport, and hence oxygen consumption by mitochondria.

The ADP/O ratio did not exhibit significant differences at any time or dose level. This may appear anomalous, but two factors must be considered in connection with these

\section{TABLE 2}

COMPARISON OF $\mathrm{Mg}^{2+}$-DePENDENT ATPase ACTIVITY in HePatic Mitochondria Isolated from Control AND DEA-TREATED ANIMALS ${ }^{a}$

\begin{tabular}{ll}
\hline Animal group & ATPase activity $^{b}$ \\
\hline Control & $42.3+4.1$ \\
DEA treated & $69.7+4.8^{r}$ \\
\hline
\end{tabular}

${ }^{a}$ Each value represents the mean $\pm S E$ of data from four animals. Treated animals were given $3.0 \mathrm{mg} / \mathrm{ml}$ (490 $\mathrm{mg} / \mathrm{kg} /$ day) DEA via the drinking water for 2 weeks.

${ }^{b}$ Expressed as $\mathrm{nmol} \mathbf{P}_{1}$ released $/ \mathrm{mg}$ protein $/ \mathrm{min}$. $c p<0.05$. findings. First, ADP/O ratios are determined when the mitochondrion is in State 3 respiration, and very little change was observed from controls during this phase of respiration. Second, mitochondria which are tightly coupled always have high ADP/O ratios, and mitochondria which are loosely coupled may or may not have low ADP/O ratios. It is of interest that the acceptor control ratio is more indicative of mitochondrial integrity than is the $A D P / O$ ratio (Chance and Williams, 1955).

The permeability of the mitochondrial membranes was determined to try to explain partially the increase in State 4 activity. Although experimental animals treated with $3.0 \mathrm{mg} / \mathrm{ml}$ DEA for 2 weeks showed no evidence of differences in permeability from controls, the possibility still exists that DEA treatment could result in alterations in permeability. The evaluation of inner and outer membrane permeability, in this study, is based on the passage of relatively large molecules through the membrane, NADH and cytochrome $c$ with molecular weights of 709 and 12,270 , respectively. A point to remember regarding NADH is that it is actively excluded from mitochondria, thus the cytoplasmic and intramitochondrial pools of this molecule are effectively segregated (Van den Bergh and Slater, 1962). These substances are considerably larger than ions, whose entry into the cell and its organelles also is selectively controlled. The possibility cannot be overlooked that DEA-treated mitochondria possess altered permeability toward small ions without any observable change in the permeability to much larger molecules. Data consistent with this statement are illustrated in Fig. 2. These are transmission electron micrographs of sections from hepatic tissue. Figure $2 \mathrm{a}$ represents untreated tissue, while Fig. $2 b$ illustrates a section from an animal treated with $3.0 \mathrm{mg} /$ ml DEA for 2 weeks. The mitochondria from DEA-treated animals are consistently spherical, and also appear larger than mitochondria from control animals. 


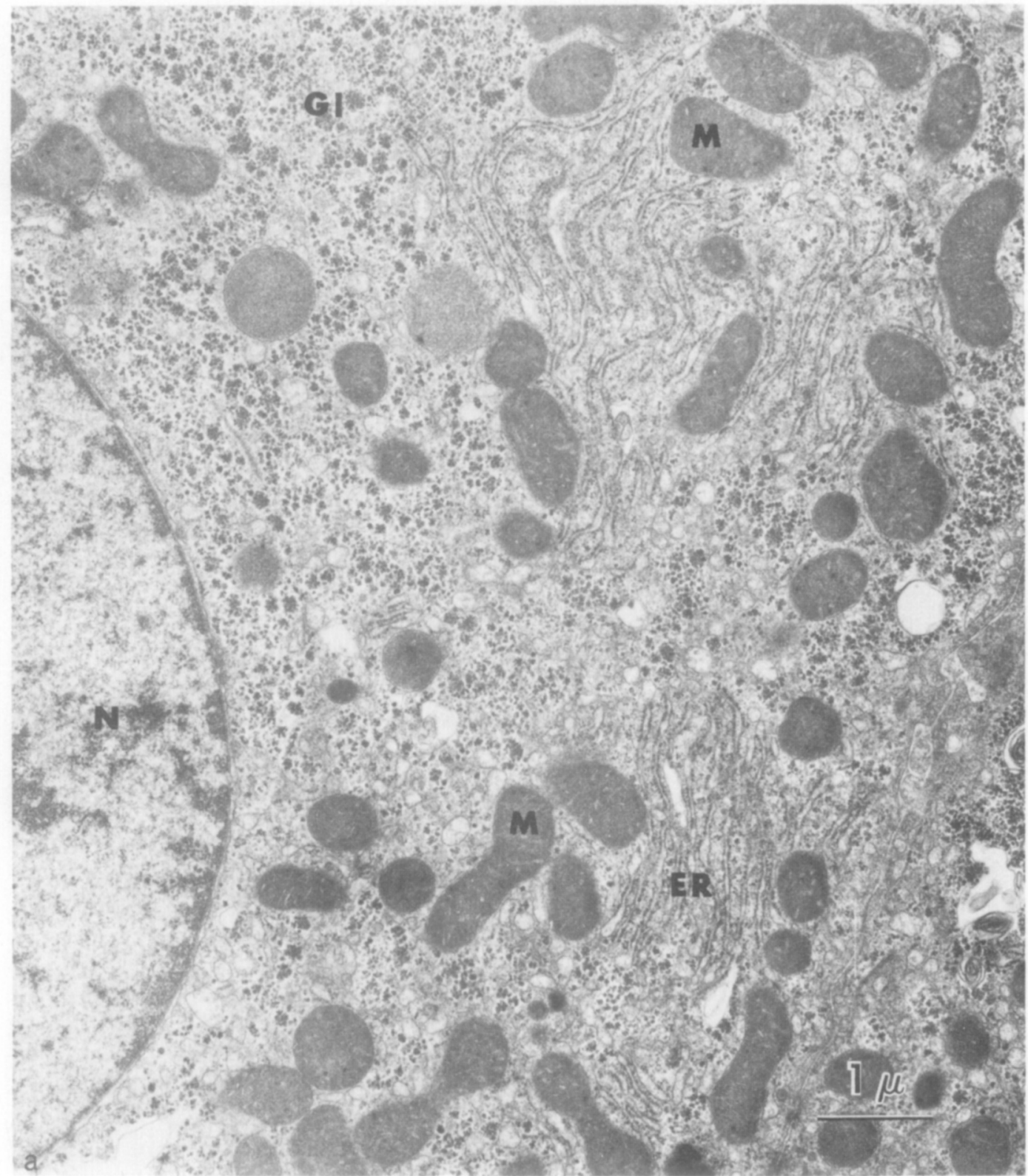

(a)

FiG. 2. Transmission electron micrographs of hepatic tissue from the rat. (a) Tissue from a control animal; (b) tissue from a rat fed diethanolamine at a concentration of $3 \mathrm{mg} / \mathrm{ml}$ in drinking water for 2 weeks. The following structures may be identified: mitochondria (M), endoplasmic reticulum (ER), cell nucleus $(\mathrm{N})$, and glycogen deposits (Gi). (a) $\times 15,750 ;$ (b) $\times 16,500$. 


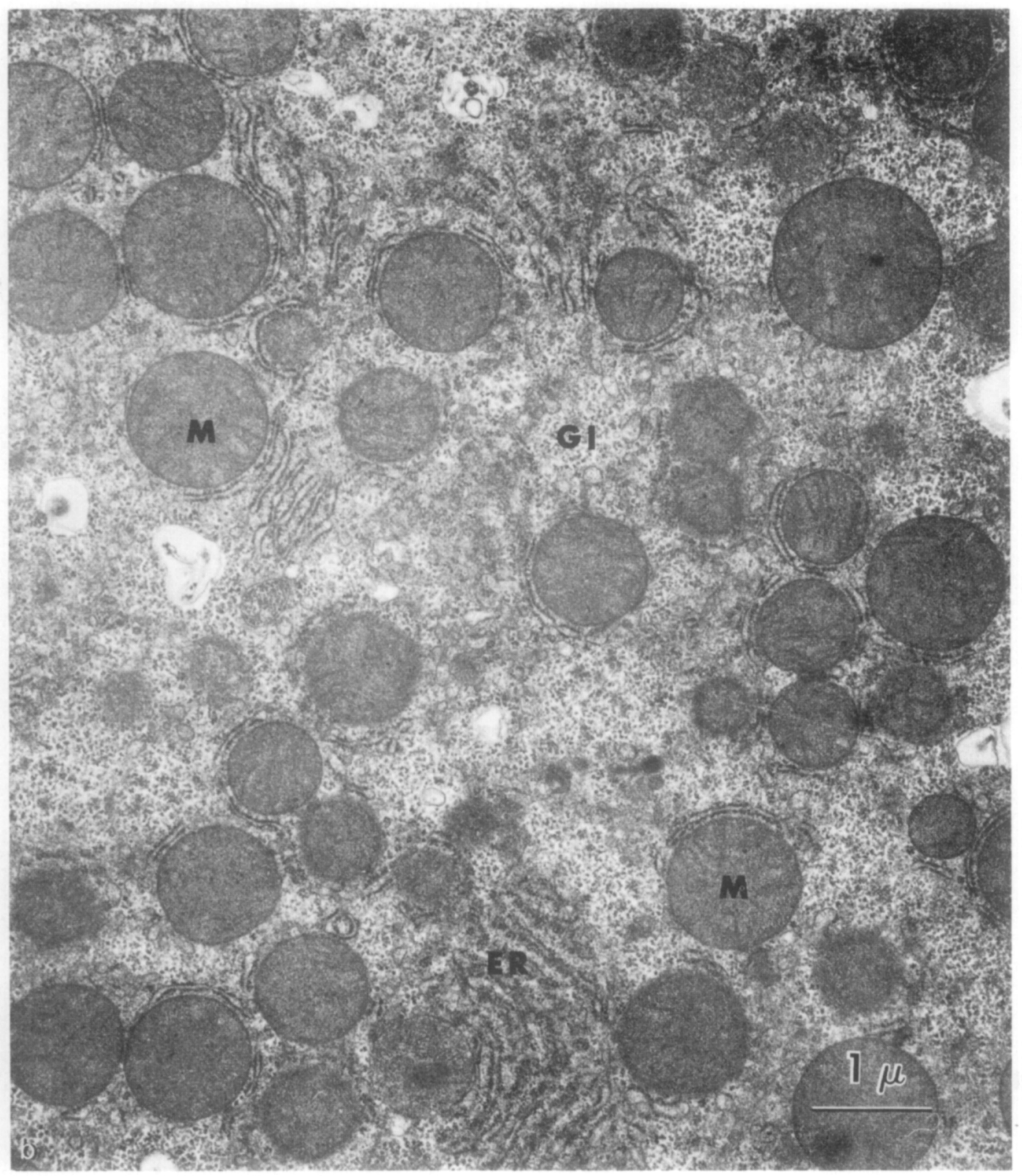




\section{DISCUSSION}

Repeated administration of DEA to rats produces alteration of function in hepatic mitochondria. No observable change is noted in this organelle upon in vitro and acute in vivo exposure to DEA. The functional alteration seen in hepatic mitochondria is due to an increase in State 4 activity caused in part, if not completely, by elevation in the $\mathrm{Mg}^{2+}$-dependent ATPase activity.

The ATPase activity in mitochondria is normally low, but it is greatly stimulated by in vitro treatment with agents that alter membrane permeability (Mitchell, 1961). Interestingly, DEA exerts no effect on State 4 activity in vitro. Barbee and Hartung (1979) noted that subacute administration of DEA inhibits the in vivo synthesis of phosphoglycerides of choline and ethanolamine. These investigators also found that DEA can serve as a substrate in phospholipid metabolism in vitro, and confirmed that it can be incorporated into hepatic phospholipids in vivo. The interaction of DEA in phospholipid metabolism may result in the incorporation of DEA into mitochondrial membrane structure as a phospholipid derivative.

Since mitochondrial function is highly dependent upon phopholipids, any alteration in phospholipid metabolism could easily result in functional change in this organelle. Atypical constituents may producc alterations in the membrane, thereby increasing mitochondrial membrane permeability. Even though no change was observed in permeability to cytochrome $c$ and NADH, the possibility still exists that alterations have occurred to allow lower molecular-weight substances easier access through the mitochondrial membrane, e.g., hydrogen ion $\left(\mathrm{H}^{+}\right)$and alkali metal ions.

Lipids are impermeable to protons and thereby act as an insulator to inhibit $\mathrm{H}^{+}$ transport (Scarpa and DeGier, 1971). CereijoSantalo (1967) noted that intact mitochondria are impermeable to $\mathrm{H}^{+}$and he concluded that the latency of ATPase activity is due to accumulation of $\mathrm{H}^{+}$ions in the membrane during that portion of respiration in which ATP is not being actively synthesized (State 4). The removal of these protons due to increased permeability or by exchange with other cations may act to unmask the latent ATPase and thus increase State 4 activity.

Influx of alkali-metal ions can increase ATPase activity when the mitochondrial membrane is made more permeable to these ions through treatment with the detergent Triton X-100 (Cereijo-Santalo, 1968). The membrane appears to be susceptible to differential structural alteration, since the author found that as the detergent concentration rose, the alkali-metal ions became increasingly more permeable in the following order: $\mathrm{I}^{+}, \mathrm{Na}^{+}, \mathrm{K}^{+}, \mathrm{Rb}^{+}, \mathrm{Cs}^{+}$. This sequence, in order of their decreasing hydrated ionic radii, may indicate the formation of flaws or pores in the membrane which increase in diameter with increasing concentration of detergent. Atypical membrane constituents may produce similar flaws or pores thereby altering the permeability to selected elemental ions.

Cockrell et al. (1966) found that mitochondria in a medium of $\mathrm{K}^{+}, \mathrm{Mg}^{2+}, \mathrm{P}_{\mathrm{i}}$, and an oxidizable substrate exhibited a stimulation of oxygen uptake and swelling when made more permeable to $\mathrm{K}^{+}$. They attribute the swelling to permeable anions which accompany the cations. Chappell and Crofts (1965) found that the influx of $\mathrm{K}^{+}$ions into mitochondria was followed by $\mathrm{H}+$ ejection in order to maintain ion balance, and mitochondrial swelling due to $\mathrm{P}_{\mathrm{i}}$ entry. It is possible that small increases in the permcability of the mitochondrial membrane toward certain cations will produce swelling and elevations in oxygen consumption without affecting the ability to synthesize ATP. This may offer an explanation for the swollen appearance of hepatic mitochondria from rats treated with DEA.

It is not possible, at this time, to define the mechanism by which DEA produces alteration of hepatic mitochondrial function and 
structure, although it presumably is related to the involvement of DEA with phospholipid metabolism. DEA does undergo incorporation to a phospholipid derivative in vivo, and, as such, is probably incorporated into mitochondrial membrane structure. It is tempting to speculate that prolonged exposure to DEA could alter lipid environments of other hepatic cellular constituents, or perhaps in other tissues, creating changes in other physiologic processes.

\section{ACKNOWLEDGMENTS}

The authors wish to acknowledge the technical assistance of Dr. R. H. Gray and Mrs. Kay Brabec in preparation and evaluation of the electron micrographs. We also thank Dr. Michael Brabec for his advice on mitochondrial isolation and metabolism. This study was supported, in part, by Environmental Health Sciences Research Training Grant 5 T01ESO0138, United States Public Health Service.

\section{REFERENCES}

Artom, C., Lofland, H. B., and Oates, J. A., Ir. (1958). In vivo incorporation of diethanolamine into liver lipides. J. Biol. Chem. 233, 833-837.

BArbee, S. J., AND Hartung, R. (1979). The effect of diethanolamine on hepatic and renal phospholipid metabolism in the rat. Toxicol. Appl. Pharmacol. 47, 421-430.

Brabec, M. J., Gray, R. H., and Bernstein, I. A. (1974). Restoration of hepatic mitochondria during recovery from carbon tetrachloride intoxication. Biochem. Pharmacol. 23, 3227-3238.

Byard, J. L., Koepki, U. Ch., Abraham, R., GolBERG, L., AND COUlSTON, F. (1975). Biochemical changes in the liver of mice fed Mirex. Toxicol. Appl. Pharmacol. 33, 70-77.

Cereijo-Santalo, R. (1967). Mitochondrial permeability and ATPase activity. Canad. J. Biochem. 45, 897-909.

Cereijo-Santalo, R. (1968). Monovalent cations and mitochondrial ATPase activity. Canad. J. Biochem. 46, 55-61.

Chance, B. (1961). The interaction of energy and electron transfer reactions in mitochondria. V. The energy transfer pathway. J. Biol. Chem. 236, 1569-1576.

Chance, B., and Hollunger, G. (1961). The interaction of energy and electron transfer reactions in mitochondria. II. General properties of adenosine triphosphate-linked oxidation of cytochrome and reduction of pyridine nucleotide. J. Biol. Chem. 236, 1544-1554.

Chance, B., and Williams, G. R. (1955). A simple and rapid assay of oxidative phosphorylation. Nature (London) 175, 1120-1121.

Chaplin, M. D., and Mulford, D. M. (1967). The effect of 3-amino-l-propanol on rat liver phospholipid metabolism. Fed. Proc. 26, 849.

Chappell, J. B., and Crofts, A. R. (1965). Gramicidin and ion transport in isolated liver mitochondria. Biochem. J. 95, 383-402.

Chojnacki, T., AND Korzybski, T. (1963). The transfer of the phosphoric ester of $N, N$-diethylaminoethanol from its cytidylyl derivative into phospholipids. Acta Biochem. Pol. 10, 233-241.

Cockrell, R. S., Harris, E. J., and Pressman, B. C. (1966). Energetics of potassium transport in mitochondria induced by valinomycin. Biochemistry 5, 2326-2334

ESTABROOK, R. W. (1967). Mitochondrial respiratory control and the polarographic measurements of ADP/O ratios. In Methods in Enzymology (S. Colowick and N. O. Kaplan, eds.), Vol, X, pp. 41-47. Academic press, New York.

Fleischer, S., ANd Rouser, G. (1965). Lipids of subcellular particles. J. Amer. Oil Chem. Soc, 42, 588-607.

Fleischer, S., Rouser, G., Casu, A., and KritCHEVSKY, G. (1967). Lipid composition of mitochondria from bovine heart, liver and kidney. J. Lipid Res. 8, 170-180.

Fostr.r, G. (1971). Studies of the acute and subacute toxicological responses to diethanolamine in the rat. Doctoral Dissertation, University of Michigan, Ann Arbor, Michigan.

GreEN, D. E. (1959). Electron transport and oxidative phosphorylation. Adv. Enzymol. 21, 73-129.

Green, D. W., ANd Fleischer, S. (1963). The role of lipids in mitochondrial electron transfer and oxidative phosphorylation. Biochim. Biophys. Acta 70, 554-582.

LeNAZ, G. (1973). The role of lipids in the regulation of membrane-associated activities. Acta Vitamin Enzymol. 27, 62-95.

Lowry, O. H., Rosebrough, N. J., Farr, A. L., AND RANDALl, R. J. (1951). Protein measurement with the Folin phenol reagent. J. Biol. Chem. 193, 265-275.

Mitchell, P. (1961). Coupling of oxidative phosphorylation to electron and hydrogen transfer by a chemi-osmotic type of mechanism. Nature (London) 191, 144-148.

Morin, R. J. (1969). In In vitro inhibition by metabolic antagonists of incorporation of ${ }^{32} \mathrm{P}$-phosphate into the major phospholipids of swine coronary and pulmonary arteries. J. Atheroscler. Res. 10, 283289. 
Pederson P. L., AND Morris, H. P. (1974). Uncoupler-stimulated ATPase activity. Deficiency in intact mitochondria from Morris hepatomas and ascites tumor cells. J. Biol. Chem. 249, 3327-3334.

ScarPa, A., AND DeGier, J. (1971). Cation permeability of liposomes as a function of the chemical composition of the lipid bilayers. Biochim. Biophys. Acta 241, 789-797.

Sibrack, L. A., Gray, R. H., and Bernstein, I. A. (1974). Localization of the histidine-rich protein in kerato-hyalin; A morphologic and macromolecular marker in epidermal differentiation. $J$. Inves. Dermatol. 62, 394-405.

Soreat, S. A. (1973). Stabilizing acetylsalicylic acid and its salts in solution. Fr. Demande 2, 143, 609.

Strickland, J. D. H., and Parsons, T. R. (1968). $A$ Practical Handbook of Seawater Analysis. Bulletin 167, Fisheries Research Board of Canada, Ottawa.
Sutton, W. L. (1963). Aliphatic and alicyclic amines. In Industrial Hygiene and Toxicology (F. A. Patty, D. W. Fassett, and D. D. Irish, eds.), Vol. II, pp. 2037-2067. Wiley Interscience, New York.

Van den Bergh, S. G., and Slater, E. C. (1962). The respiratory activity and permeability of housefly sarcosomes. Biochem. J. 82, 362-371.

Wattiaux-De Coninck, S., AND Wattiaux, R. (1971). Subcellular distribution of sulfite cytochrome $c$ reductase in rat liver tissue. Eur. $J$. Biochem. 19, 552-556.

Welch, A. D., and Landau, R. L. (1942). The arsenic analog of choline as a component of lecithin in rats fed arsenocholine chloride. J. Biol. Chem. 144, 581588.

Wells, I. C., AND Remy, C. N. (1961). Inhibition of de novo choline biosynthesis by 2-amino-2methyl-1-propanol. Arch. Biochem. 95, 389-399. 